$1 / 26-9585(1)$

UCRL-ID-120133

\title{
Plutonium Disposition:
}

Summary of Public and Governmental Support Issues

Alan Pasternak

March 31, 1995

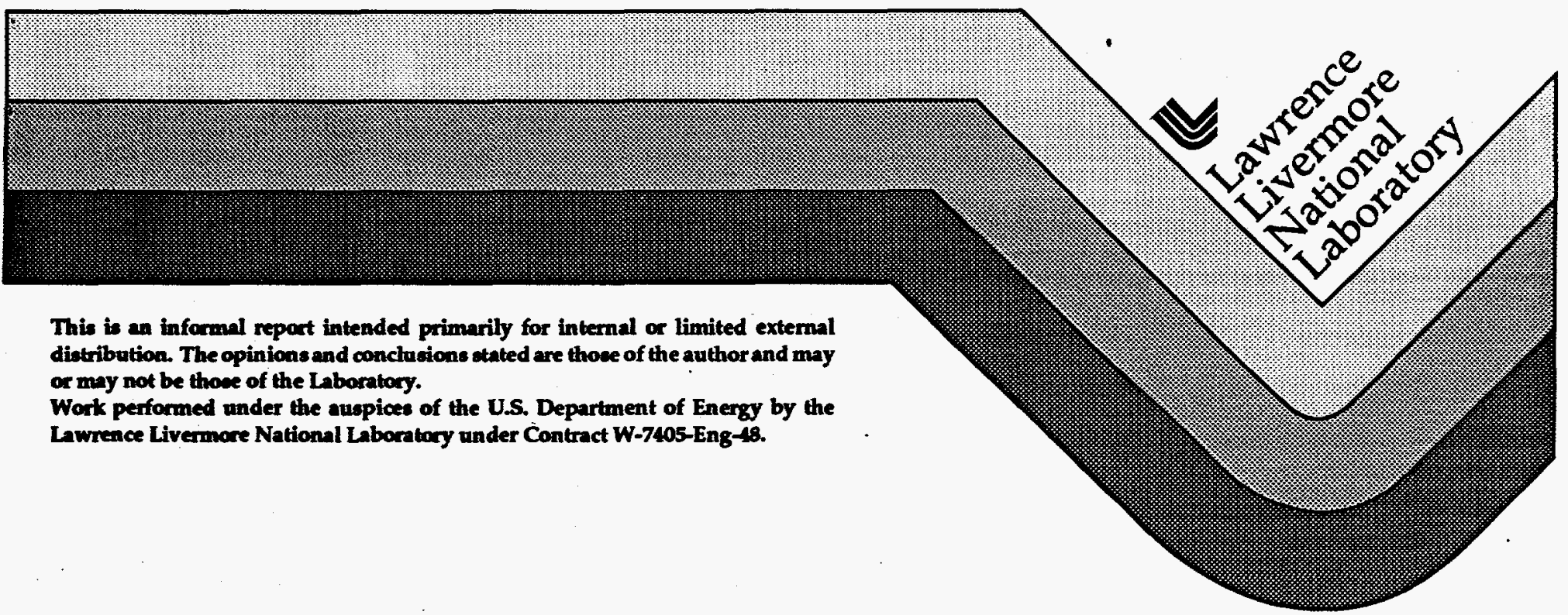




\section{DISCLAIMER}

This report was prepared as an account of work sponsored by an agency of the United States Government. Neither the United States Government nor any agency thereof, nor any of their employees, make any warranty, express or implied, or assumes any legal liability or responsibility for the accuracy, completeness, or usefulness of any information, apparatus, product, or process disclosed, or represents that its use would not infringe privately owned rights. Reference herein to any specific commercial product, process, or service by trade name, trademark, manufacturer, or otherwise does not necessarily constitute or imply its endorsement, recommendation, or favoring by the United States Government or any agency thereof. The views and opinions of authors expressed herein do not necessarily state or reflect those of the United States Government or any agency thereof. 


\section{DISCLAIMER}

Portions of this document may be illegible in electronic image products. Images are produced from the best available original document. 


\title{
Plutonium Disposition: \\ Summary of Public and Governmental Support Issues
}

LPDS -94-37

\author{
Alan Pasternak \\ University of California, Lawrence Livermore National Laboratory
}

\begin{abstract}
Obtaining strong public and governmental support for the plutonium disposition program and for the projects comprising the selected disposition options will be essential to the success of the program in meeting non-proliferation goals established as national policy. This paper summarizes issues related to public and governmental support for plutonium disposition. Recommendations are offered which rest on two fundamental assumptions: 1) public and political support derive from public trust and confidence, and 2) despite widespread support for U.S. non-proliferation goals, establishing and operating facilities to carry out the program will entail controversy.

Documentation for the Administration's policy on non-proliferation as it relates to plutonium disposition is cited and summarized as background for ongoing planning efforts by the Department of Energy (DOE).

Consensus is a reasonable goal for efforts to secure public and governmental support for the plutonium disposition program and its elements; unanimity is very unlikely. The program will be aided by the popular recognition of the importance of the nation's nonproliferation goals, the potential for an energy dividend if an energy production option is selected ("Swords to Plowshares" metaphor), the possibility of influencing disposition decisions in other countries, and the clear need to do something with the excess material ("the no action alternative" will not suffice). Anticipated difficulties in securing public and governmental support include the often encountered exaggeration of the real hazards associated with plutonium; the multiplicity of "publics" which may be involved (some are defined geographically others by issues), including state and local governments; the political attractiveness and ability of extended storage to delay decisions on disposition; society's avoidance of decision making for waste disposal of all kinds; and the ability of even relatively small opposition groups to exercise political and legal leverage.
\end{abstract}

Recommendations reflect a dual approach which incorporates features of public process to earn public support and project characteristics to minimize unnecessary delay.

Recommended features of process include a clear separation of operational and regulatory functions; public information, education, and involvement programs; and the presence and accessibility of agency leaders. With respect to avoiding delays, the value of a strong legislative or administrative mandate; use of existing federal facilities and sites - preferably remote but avoiding environmentally sensitive areas; and a preference for options which can be implemented with few, rather than many, licenses.

While the emphasis of this summary is on process, the importance of program performance in maintaining public and political support and confidence is cited. 


\section{Process and Acceptance}

In the United States, institutional issues have come to play every bit as important a role as science and technology in arriving at major federal decisions. It is vital that federal agencies, in developing policy initiatives, recognize the key roles that building public and political support and the timely satisfaction of requirements of process and openness play in the success or failure of programs and projects. Experience has shown that projects endorsed by selection processes which fail to take these factors into account may be seriously delayed or possibly never implemented. Therefore, agencies need to consider both the public process by which decisions are reached and the actions needed to build sufficient governmental, political, and public support if they hope to achieve acceptance of the policy or program.

The National Environmental Policy Act ${ }^{1}$ requires a full, complete and public analysis of proposed major federal actions and alternatives. This process requires preparation of an Environmental Impact Statement (EIS). Successful challenges to project approvals have been based on allegations that government agencies have not fully complied with this law or with similar state laws.

For major federal actions a formal process must be announced and followed. The terms "public," "open," and "transparent" all apply to the process. "Public" means that there must be opportunity for input and participation by the public. "Open" means that appropriate announcements, presentations, and, in some cases, decisional meetings, must be available and open to the public and the news media. "Transparent" means that the actual issues and considerations that are factors in the decisions be made known to the public rather than having public activities for show while a hidden agenda actually drives the decisions. These characteristics benefit other agencies and levels of government as well as the public. In short, major governmental programs must be undertaken in partnership with the people.

At the outset of any program, it is necessary to decide and state clearly what the program goals are. Even the statement of goals and supporting explanations may be contentious. Publication of a Notice of Intent or a Preliminary EIS is a first public step which is used to obtain public comment and to refine the statement of goals and objectives. This step is an integral part of today's decision making process.

Implementation of policy is through programs and projects. Before a proposed project can become a reality, government must take additional steps beyond policy formulation. A budget must be developed by the appropriate agency, approved by the Administration (Office of Management and Budget), and submitted to Congress for authorization and appropriation. Often, regulations must be adopted in a rulemaking governing the siting, construction and operation of the planned project. Finally, the proposed project will be evaluated against the regulations in a regulatory licensing or permitting process. Both rulemaking and permitting are open processes where the public and interest groups may play a role as parties or intervenors. Opponents of adopted policies and programs will sometimes attempt to gain a practical reversal of basic policy by intervening in the regulatory process for a specific project. Policy makers and program managers need to be prepared for this possibility.

This report deals with concepts and processes involving institutional support that are likely to be important in developing and carrying out government policy on disposition of

1 National Environmental Policy Act (NEPA), U.S.C. 4321 et seq. 
excess weapons material, specifically plutonium. It is part of the review called for in the President's statement on "Nonproliferation and Export Control Policy," September 1993.2 (Issues related to disposition of High Enriched Uranium (HEU) are outside the scope of this paper.)

\section{Administration Policy and Goals: The President's Statement of September 27, 1993: "Nonproliferation and Export Control Policy" and the Department of Energy's "Notice of Intent to Prepare a Programmatic Environmental Impact Statement (PEIS) for Storage and Disposition of Weapons-Usable Fissile Materials"}

The overall purposes toward which U.S. policy is directed are to reduce to a minimum the risk of proliferation of nuclear weapons states and the risk of terrorists acquiring nuclear materials. Ideally, these risks should be reduced to such a low level that the world's peoples do not have to live with fear of such threats. On September 27, 1993, the President issued a statement on Nonproliferation And Export Control Policy to establish "a framework for U.S. efforts to prevent the proliferation of weapons of mass destruction and the missiles that deliver them." As one of the key elements of the portion of the policy on fissile material, the U.S. will:

Initiate a comprehensive review of long-term options for plutonium disposition taking into account technical, nonproliferation, environmental, budgetary and economic considerations. Russia and other nations with relevant interests and experience will be invited to participate in this study.

On June 15, 1994, the U.S. Department of Energy issued a Notice of Intent to Prepare a Programmatic Environmental Impact Statement (PEIS) for Storage and Disposition of Weapons-Usable Fissile Materials. ${ }^{3}$ The Summary of the Notice of Intent states (in part):

The changes in the aftermath of the Cold War have significant implications for the management of weapons-usable fissile materials (primarily plutonium and highlyenriched uranium). The large reductions in nuclear weapons agreed to by the United States and Russia reduce our national security requirements for fissile materials and, as a result, storage and disposition decisions for these materials will be required.

The national policy outlined by the President in September 1993 is to seek to eliminate where possible the accumulation of stockpiles of highly-enriched uranium (HEU) or plutonium, and to ensure that where these materials already exist they are subject to the highest standards of safety, security and international accountability. In addition, the President has initiated a comprehensive review of long-term options for plutonium disposition, taking into account technical, nonproliferation, environmental, budgetary and economic considerations.

The Notice of Intent restates the major principles of U.S. nonproliferation policy outlined by the President in his statement and sets forth the Department's objectives in furtherance of this policy as follows:

2 The White House, Office of the Press Secretary, "Fact Sheet. Nonproliferation and Export Control Policy," September 27, 1993.

3 Tara O'Toole, M.D., M.P.H.; Assistant Secretary, Environment, Safety and Health; June 15, 1994. 
- To strengthen national and international arms control efforts by providing an exemplary model for storage of all weapons-usable fissile materials and disposition of surplus weapons-usable fissile materials;

- To ensure that storage and disposition of weapons-usable fissile materials is carried out in compliance with environmental, safety and health standards;

o To minimize the prospect that surplus United States weapons-usable fissile materials could be reintroduced into the arsenals from which they came and therefore increasing the prospect of reciprocal measures by Russia and other nuclear powers;

- To minimize the risk that surplus United States weapons-usable fissile materials could be obtained by unauthorized parties; and

o To accomplish these objectives in a timely and cost-effective manner.

The Notice cites a report by the National Academy of Sciences (NAS), "Management and Disposition of Excess Weapons Plutonium" as "a starting point for evaluating alternatives regarding the long-term storage and disposition of plutonium." 4 The Notice quotes a conclusion of the NAS report that "the existence of surplus fissile materials worldwide constitutes a "clear and present danger to national and international security."

The Notice reports the following conclusion of the Academy study:

None of the options yet identified for managing this materials can eliminate this danger; all they can do is to reduce the risk. Moreover, none of the options for long-term disposition of excess weapons plutonium can be expected to substantially reduce the inventories of excess plutonium from nuclear weapons for at least a decade.

And the Notice reports the following recommendation of the Academy study:

It is important to begin now to build consensus on a road map for decisions concerning long-term disposition of excess weapons plutonium. Because disposition options will take decades to carry out, it is critical to develop options that can muster a sustainable consensus.

The Notice goes on to discuss disposition options identified by the NAS as meeting the "spent fuel standard." 5

* Mixed Oxide fuel alternative, in which the surplus plutonium would be used as fuel in existing, modified, or new nuclear reactors, that would consume a fraction of the plutonium and embed the rest in highly radioactive spent fuel similar to that now produced by commercial power reactors, and which would be stored and ultimately disposed of in a geologic repository;

\footnotetext{
4 "Management and Disposition of Excess Weapons Plutonium," Committee on International Security and Arms Control, National Academy of Sciences. National Academy Press. Washington, D.C. 1994.

5 As reported in the Department's Notice: "The National Academy of Sciences recommended that options for long-term disposition of plutonium should seek to meet a 'spent fuel standard' in which the plutonium is as inaccessible for weapons use as the plutonium in spent fuel from commercial power reactors."
} 
* Immobilization alternative, in which the surplus plutonium would be vitrified or embedded in a ceramic or other material, either alone or mixed with radioactive high-level wastes, to form glass or ceramic logs for ultimate disposal in a geologic repository; and

* Geologic disposition alternative in which plutonium in some other acceptable form would be placed directly in suitable canisters and buried in deep boreholes drilled into the earth, or in a mined geologic repository.

The Notice indicates that it will be "prudent to consider further steps to reduce long-term proliferation risks," and includes "alternatives that result in the plutonium becoming essentially inaccessible or destroyed."

* Accelerator based conversion, in which a large fraction of plutonium would be fissioned in a sub-critical reactor aided by neutrons produced by an accelerator, and

* "Deep Bum" Reactors, in which the plutonium is fissioned so completely in reactors, without spent fuel reprocessing and recycling, that only a small amount of plutonium would remain in the spent nuclear fuel.

The PEIS will discuss these and other alternatives for disposition of excess plutonium. Other "exotic" alternatives discussed by the NAS report are sub-seabed disposal, ocean dilution, underground detonation, and disposal in space. The NAS report rejects these "on grounds of retrievability, cost, delay, environmental concerns, or conflict with existing policies and international agreements." 6

The policy being developed for plutonium disposition and storage is for excess United States weapons material. As quoted on the preceding page, the Notice identifies one of the Department of Energy's objectives in furtherance of U.S. nonproliferation policy as "providing an exemplary model for storage of all weapons-usable fissile materials and disposition of surplus weapons-usable fissile materials." However, Russia, China, France and the United Kingdom, identified as nuclear weapons states under the NPT, may not wait for the U.S. lead but rather establish their own policies. ${ }^{7}$ U.S. policy, adopted in the 1970s, to abandon reprocessing in order to foster non-proliferation has been ignored by a number of other nations. Britain, France, Russia, and Japan reprocess civilian fuel. (Argentina, Belgium, Brazil, Germany, South Africa, South Korea, Taiwan, and the U.S. have reprocessed civilian fuel in the past.) ${ }^{8}$ The Russians report they have successfully tested MOX fuel which incorporates weapons-grade plutonium in fast reactors. They are

\footnotetext{
6 NAS Report, Executive Summary, page 17.

7 Nuclear News for October, 1994 reports that British Nuclear Fuels plc (BNFL) submitted a proposal to the U.K. Foreign Office that plutonium from dismantled weapons in the former Soviet Union be incorporated into mixed uranium/plutonium oxide (MOX) fuel at the company's Sellafield plant for use in light water reactors throughout the world. According to Nuclear News, BNFL has started production at a demonstration MOX fabrication plant, made a shipment to the Beznau plant in Switzerland last June, and recently started construction of a full-scale MOX fabrication plant. (Nuclear News, VOL. 37/NO. 13, p. 64.)

${ }^{8}$ Nuclear Weapons Supply and Demand," by Michael M. May; American Scientist, Volume 82, No. 6. November-December 1994. Page 526.
} 
just beginning studies of plutonium utilization in thermal reactors. They favor a closed fuel cycle to enhance efficiency and decrease radioactive waste. ${ }^{9}$

Even if disposition of some weapons material can be accomplished within a few years, and regardless of what plans are chosen for ultimate disposition, safeguarded storage for excess weapons material will be required for at least ten years, and probably for many years beyond that. It will be vital to identify and establish-an accounting system under international auspices for all separated plutonium both in and outside of national security material stockpiles, and for the U.S. to participate fully in that system. The sooner this system can be established, the greater will be the credibility and confidence of the nonproliferation regime.

An important issue that must be aired in developing the plutonium disposition policy involves the potential use of excess weapons material as fuel for generation of electric power from nuclear reactors. Although reprocessing is not a direct issue here since the excess plutonium has already been separated, this issue touches upon the question of whether the U.S. and other nations will reprocess spent reactor fuel to separate additional plutonium to make new fuel for conventional or advanced power reactors in the future. Since the current U.S. position on this point is different from that of a number of other nations, this matter could become a contentious and complicated subject to deal with in the area of public and governmental support.

\section{Defining and Measuring Public Support}

The ultimate measure of public support will be the successful implementation and completion of the projects and programs that are selected to meet the goals in the President's statement of September 1993 and in the PEIS. However, even to formally adopt a policy and move toward implementation, a number of necessary steps will, in fact, become tests of public and governmental acceptance. An early test may arise if and when legislation is proposed to provide a statutory base for the program. In this case, political support will be established by a majority of votes cast in the Congress to pass such legislation. The votes of elected representatives will be influenced by their perception of the attitudes of their constituents. Measuring public attitudes on political issues is an uncertain undertaking.

This discussion concerns selecting policies and options which have the potential to win a high degree of public support. Implementation of the federal statutory or administrative mandate may be challenged at other levels (state, local, etc.) and by action in administrative or judicial arenas. Even small groups can take their challenges to the courts, or carry out campaigns in the media. It is impossible to anticipate every action or avenue of opposition to every proposed alternative.

9 Foreign Trip Report, Russia - October 1994 by W. G. Sutcliffe, LLNL. Summary of paper "Management of Plutonium in Russia" by Victor Murogov presented at the NATO Advanced Workshop on "Mixed Oxide (MOX) Exploitation and Destruction in Power Reactors." 


\section{Institutional Considerations in Program and Project Planning}

In the area of public and governmental support, our objective is to select, design, organize, and manage a plutonium disposition option that 1) will merit and earn a sufficiently high degree of public and governmental support to establish a consensus for implementation, and 2) can be implemented in a timely manner and achieve the objectives established as public policy by the Congress and/or the Administration without unnecessary delay even in the presence of some level of controversy. The project must be able to reach its authorized objectives and do so while complying with the spirit and letter of all requirements of procedure, openness, and public involvement. These requirements should be viewed as means to, or facilitators of, public support and not as constraints or hurdles. To be viable, a project must not only be able to meet all health, safety, and environmental standards and contribute significantly to non-proliferation goals, but also must have a high probability of being implemented, i.e., licensed, constructed, and operated, in a timely manner - even in the face of opposition. Success depends on selection, design, organization, and management of a disposition option that maximizes public and governmental support and minimizes vulnerability to disruption and unnecessary delay through unnecessary administrative process, legal challenges, or campaigns designed to undermine public confidence. Nevertheless, managers need to be prepared for surprises, unexpected challenges, and schedule delays.

Unlike other criteria, such as compliance with safety requirements, environmental requirements, or technical feasibility, universal public and governmental acceptance is not, nor is it likely to be, an achievable goal for the plutonium disposition program. Consensus is a reasonable goal; unanimity is not. For reasons that will be discussed, plutonium disposition will be controversial whatever option is selected. The word "controversial" describes something about which there is, or is likely to be, a dispute or a debate, i.e., a clash of opposing opinions. By definition, a controversial project lacks universal approval or acceptance. For this reason, planning for both the plutonium disposition program and any specific selected disposition options or projects within that program should assume that, despite serious efforts to develop a manifestly safe and effective project, accommodate and satisfy public concerns, and secure public support, there will be some level (hopefully small) of opposition from some segments of the public and some portions of the political spectrum. It is prudent to anticipate some level of opposition and controversy. 10

In striving for consensus, it may be useful to think of a "threshold of acceptability" rather than universal satisfaction of all concerns, to indicate a level of public acceptability or support which may constitute a necessary, but not necessarily sufficient, condition for project or program success. The first application of this concept will occur if and when enabling legislation is sought to provide a statutory base for the program. This threshold of political acceptability is clear: a majority of votes in the Congress with any votes in excess of one-half plus one of those cast providing a margin of safety.

10 As noted in the Executive Summary of the Final Report of the Secretary of Energy Advisory Board Task Force on Radioactive Waste Management, "Earning Public Trust and Confidence: Requisites for Managing Radioactive Waste," November 1993:

"... the Task Force recognizes that, regardless of what DOE does, some segments of the public will never accord it much trust and confidence. They are opposed as a matter of principle or tactics to the missions the Department of Energy has either been charged to undertake by Congress or has undertaken on its own discretion." 
One might assume that legislative support will reflect public acceptability, but there are different "publics," and attitudes of ten change over time. One advantage of legislation is that the support-building process can work in both directions. The legislative process, with issues openly debated and a clear resolution embodied in statute, can influence and contribute to public confidence and trust, reduce the program's vulnerability to legal challenges in the courts, and guide administrative action.

However, in politics nothing is certain or forever; legislative mandates can be undone both by the courts and by lack of political will in administering and carrying out the law. But it is more difficult to disrupt a program that has a statutory base than one that lacks such a foundation. Alternatively, a program based on a strong administrative mandate that is well publicized, is carefully explained to the public, incorporates public outreach and other recommendations of this review and has the backing of key congressional leaders as well as the necessary funding appropriation by Congress will be necessary and may suffice.

The selection, design, initiation, conduct, and conclusion of the plutonium disposition project option should all be conducted so as to achieve a high level of public and governmental acceptance and to achieve the goals established as public policy, in a timely manner, without unnecessary delay, despite opposition from some. ${ }^{11}$

\section{Some Anticipated Bases for Public and Governmental Support and Opposition}

The plutonium disposition program starts out with both pluses and minuses in the effort to gain public and political support.

The pluses include:

- As a matter of national security, the public and our political leaders attach great importance to reducing the risks of weapons proliferation. In his statement of September 27, 1993, the President stated, "Our national security requires us to accord higher priority to non-proliferation and to make it an integral element of our relations with other countries." The program's objective is to render weapons grade fissile material non-usable or nonavailable for weapons use. The program is clearly a manifestation of the end of the cold war and is both a necessary effort to deal with some of the remnants of an era that was a dangerous time and to assure a more stable and secure future. On a national or regional level, it can be anticipated that support will be generated by the knowledge that the need to dispose of excess plutonium is a welcome development. The public and its representatives will want assurance that the job will be done safely and efficiently and that the program and selected options will, in fact, contribute to nonproliferation objectives. It is far better to have weapons plutonium recognized as excess

11 Public and governmental support and the minimization of vulnerability of the selected plutonium disposition option are both important to the achievement of legitimate public policy objectives. This is underscored by the following statement in the report of the Advisory Board Task Force (page 17):

"On a more pragmatic level, trust and confidence are generally essential for effectively carrying out activities in the public sphere. The genius of American government -- checks and balances, division of powers, federal structure -- is that it provides innumerable opportunities for opponents to delay, frustrate, and otherwise block what others call progress." 
and requiring disposition than to be in the opposite position of needing to make and deploy more against dangerous international contingencies.

- The program may constitute a "Swords to Plowshare" metaphor. Depending on which disposition options are selected, plutonium disposition may produce a useful energy dividend through use of the excess plutonium in MOX reactor fuel.

- There is an opportunity to set precedents for international priorities and standards and thereby to directly influence Russian disposition decisions.

o The need to take action is clear. The "no action alternative" will not suffice. The materials exist and, in the long run, something must be done with them to minimize the risk of proliferation. The purpose of the program is proper, safe disposition of the fissile materials to achieve these goals. While in the short term, only some of the material must be dealt with on an urgent basis, early demonstration of one or more methods of disposition is important to establish programmatic momentum as soon as practicable.

On the minus side are the following:

o The material whose disposition is the object of the program is plutonium, both a weapons material and a reactor fuel about which there is much misinformation and fear. Because plutonium is often sensationally and incorrectly characterized as "the most dangerous substance known to man," many people will be apprehensive at the idea that plutonium may be brought into their community, county, or state for storage, processing, use as a fuel, or disposal. Public concerns may be aroused even in areas where similar activities have gone on routinely for years. It will be very important to provide timely and accurate information to the public and the media about plutonium, its physical and chemical form, the actual hazard presented ${ }^{12}$, methods and accumulated experience for safe handling and storage, means to prevent theft or diversion, and society's beneficial use of other long-lived radionuclides.

o There is a danger that interim storage measures may delay making decisions about permanent disposition solutions. Interim measures, which have the appeal of appearing reversible, are often the path of least political resistance; they allow decisions on controversial issues to be postponed while the issue is subjected to "further study." A related concern is that without clear. identification of a permanent disposition option, residents in the vicinity of the interim storage facility will voice the fear that it will become permanent by default if not by design. The National Academy report warns against indefinitely extended storage, and does so for reasons directly related to proliferation concerns. ${ }^{13}$

12 Examples are "A Perspective on the Dangers of Plutonium," by W.G. Sutcliffe, R. H. Condit, W. G. Mansfield, D.S. Myers, and D. W. Layton, University of Califormia Lawrence Livermore National Laboratory, October 3, 1994; and Merril Eisenbud, "The Plutonium Perception," Guest Editorial in HPS [Health Physics Society] Newsletter, December 1994.

13 The reasons cited are, "(1) the negative impact that maintaining this material in forms readily accessible for weapons use would have on nonproliferation and arms reduction, (2) the risk of breakout, and (3) the risks of theft from the storage site." NAS report, page 237. 
Plutonium pits from dismantled weapons are now stored at the Pantex plant near Amarillo, Texas for an indefinite period of time. ${ }^{14}$ The Department of Energy has completed an Environmental Assessment with a finding of no significant impact. Currently, there is no restriction on the duration of storage, but there is a 12,000 pit storage limitation until a sitewide EIS has been completed and a record of decision (ROD) issued. This is to be done by November 1996. The State of Texas understands that the ROD for the programmatic EIS will analyze the options for long-term storage and that Texas will be afforded an opportunity to review and comment during the EIS process. 15

- Society is averse to making the decisions associated with the disposal of all wastes: municipal, hazardous, and radioactive, and most disposition options will involve disposal of wastes. In recent years, it has become increasingly more difficult to establish new disposal facilities of all kinds. Examples are the delays in the Department of Energy's development of permanent repositories for high-level waste and spent fuel (Yucca Mountain project in Nevada), for transuranic wastes (Waste Isolation Pilot Plant (WIPP) in New Mexico), and the delays experienced in all state programs to develop new disposal facilities for low-level radioactive waste. In most cases, institutional and political factors have been at least as significant as technical issues in causing these delays. Disposal projects provide attractive opportunities to raise issues not directly related to disposal safety such as one state or region accepting waste from another and opposition to the activities which use radioactive materials and generate the wastes. Any disposition option except long-term storage will involve disposal of nuclear waste. It should be assumed in development of any plan that waste disposal issues will result in controversy and may become the focus of opposition.

\section{There Are Many Publics}

The kinds and levels of public concerns about a controversial program or project will vary geographically and in other ways. The concerns of those who live close to a project (same town or county) will not necessarily be the same as the concerns expressed by those who live farther away (same state or region or even a different region). Generally speaking, for those close to the site of a controversial project, safety and potential local environmental issues will be the primary concerns.

But controversy is not a function of proximity only. Among those sufficiently far away from the site that their immediate personal safety cannot be said to be a concern, other broad policy concerns may be reflected in opposition to the project. For example, those who believe that any use of nuclear energy creates a risk of proliferation can be expected to oppose any disposition option that involves producing energy from plutonium in a reactor. But even direct disposal without energy production may draw suspicion and opposition. Some may believe that any demonstration that plutonium can be handled safely and without harm to workers, the public, or the environment constitutes an accumulation of experience, and demonstration of safe handling in one application may foreshadow other uses of plutonium in other applications which they oppose.

14 "Texas Bunkers House Nuclear Arms Material," by Thomas W. Lippman, (Washigton Post) Los Angeles Times, November 20, 1994.

15 Phone conversation with Jerry Johnson, Amarillo Area Manager for DOE, October 28, 1994. 
Public attitudes can change over time. Local support for a project, encouraged by information on important public purposes to be served, information on safety, and by anticipated local jobs and other benefits, can evaporate in the face of demonstrations and unfavorable publicity generated by project opponents.

With respect to federal programs and projects, local and state political leaders constitute another public. Although disposition of HEU differs significantly from disposition of plutonium, a current example of the controversy that can arise if nuclear materials are involved is unfolding now in South Carolina and involves HEU from foreign research reactors. The State of South Carolina has challenged the authority of the Department of Energy to bring HEU from foreign research reactors to Savannah River. Discouraging the use of HEU in research reactors is a measure adopted by the U.S. Government as part of its non-proliferation policy, so the U.S. wishes to facilitate return of HEU fuel. Nevertheless, through litigation in federal court, South Carolina was successful, for a time, in blocking a shipment of 153 fuel assemblies. The state demanded that the DOE prepare an Environmental Impact Statement which the department said could take two years. According to a newspaper account, "Secretary of State Warren M. Christopher had submitted testimony to the court saying that failure to take back the fuel "would damage broad U.S. foreign policy interests."'16 The courts have resolved the dispute in favor of the DOE. 17

\section{Earning Public and Governmental Support}

Emphasis on the following features or characteristics, if incorporated in project planning and information programs, can help the plutonium disposition project maximize public and governmental acceptance:

o The non-proliferation objectives and the "Swords to Plowshares" metaphor, where appropriate. The project will benefit from public understanding of its contribution to non-proliferation objectives. (See discussion on page 8.)

- For disposition options, the use of existing, proven technology such as existing commercial reactors will promote public confidence. Alternatively, the use of new technologies with clear safety, efficiency, or cost benefits as compared with existing technologies can also help win public confidence. The key is public understanding of the match of technology to the job to be accomplished.

- Location of the project at a remote site and in an area with minimum environmental sensitivity. (For the new reactor options, siting studies for the New Production Reactor should be reviewed.) Handling of hazardous materials at a remote site is an obvious way to reduce the public's apprehensions about the safety of the operation. However, remote siting and avoidance of environmentally sensitive areas don't necessarily go hand-inhand. Often, it's the reverse. Careful studies and good communications with the local public are essential.

16 "Spent Nuclear Fuel Can Enter South Carolina," by Matthew L. Wald, New York Times, September 24, 1994. See also "S. Carolina Gets Reprieve on Nuclear Waste Dump," Associated Press, Los Angeles Times, September 28, 1994.

17 "Nuclear Rods Bound for South Carolina to Be Unloaded. U.S. Tells Court That Further Delay on Storage of Waste from Europe Could Affect Safety." The Washington Post, September 30, 1994 (Reuter) 
- A clear separation of operational and regulatory functions with rigorous regulation of project health, safety, and security by an independent federal agency, e.g., the U.S. Nuclear Regulatory Commission (NRC).

Even if a government agency is the developer or operator of the disposition facility(ies), separation of regulatory and operational functions is important to maintain credibility and the avoidance of real or perceived conflicts of interest. The approach could follow the existing statutory scheme for the Yucca Mountain high-level waste repository where the DOE, as developer/operator, will apply to the NRC, as regulator, for a license to construct and operate the disposal facility. The Congressional Office of Technology Assessment suggests a role for the Defense Nuclear Facilities Safety Board (DNFSB) as an outside party to fairly and independently review DOE's conduct of dismantlement and temporary storage activities. ${ }^{18}$ The scope of plutonium disposition activities is much larger than dismantlement and temporary storage. In any event, the thrust of the recommendation made here relates to regulatory oversight, rather than advisory functions, and this is a job for the NRC.

- Utilization of an existing facility or site, preferably a government facility on government land.

If there is no new commitment of land to industrial use, i.e., no new "and use issue, licensing will be simplified and public acceptance enhanced. Should a power reactor disposition option be selected that would use a mixed oxide (MOX) fuel containing weapons plutonium and uranium, the operating WPN2 reactor in Washington State (a General Electric BWR) or the Palo Verde Nuclear Generating Station reactors (ABB-CE System 80 PWRs) in Arizona might be candidates even though these are not U.S. government facilities. However, the operating WPN reactor is on the government's Hanford reservation. This use of the WPN reactors is being studied by a consortium led by Battelle PNL and is known as the "Isaiah Project." 19 All newer U.S. reactors are also capable of using MOX fuel.

A more detailed evaluation of these reactor options for plutonium disposition should include a review of the NRC's consideration of the Generic Environmental Impact Statement on Mixed Oxides (GESMO), which was

18 "Dismantling the Bomb and Managing the Nuclear Materials," U.S. Congress Office of Technology Assessment, September 1993, (OTA Report), page 154.

19 Considerations related to a possible decision by the Washington State Public Power Supply System (WPPSS) to complete the WPN-1 (1240-MWe) and WPN-3 (1259-MWe) reactors (65 and 75 percent complete, respectively), with WPN-1 and the operating WPN-2 reactors to burn MOX for disposition of excess weapons-grade plutonium, have been reported in the April, May, June, and October 1994 issues of Nuclear News. The City of Seattle, a member of the WPPSS is reported to be opposed to this plan because of concerns about liability. The Bonneville Power Administration (BPA) recommends termination of the uncompleted plants. The WPPSS Board voted on May 13 to terminate WNP- 1 and -3 effectively January 13, 1995. Nuclear News reports that WPPSS has proposed a plan to DOE to convert WNP-1 and -2 (both at Hanford, Washington) to MOX to dispose of weapons-grade plutonium and generate power. WPPSS hopes for a decision by DOE before the January 13, 1995 deadline, but Nucleonics Week for December 8 , 1994, reports that DOE's schedule for decision is Spring 1996. 
terminated in $1977 .{ }^{20}$ The controversy at that time was fueled by concerns over reprocessing and proliferation which resulted in a presidential policy decision that the U.S. would not reprocess spent reactor fuel to recover plutonium for recycling in reactors. The situation today with disposition of weapons grade plutonium is very different. The plutonium is already separated, and once-through use of MOX doesn't require reprocessing or a long-term decision about the pros and cons of reprocessing of commercial spent fuel.

o Inspection by the International Atomic Energy Agency (IAEA).

A "key element" of the President's September 27, 1993 Nonproliferation and Export Control Policy is to "Submit U.S. fissile material no longer needed for our deterrent to inspection by the International Atomic Energy Agency." Inspection by IAEA will provide added assurance to the public that all fissile material is accounted for and that risks of theft and proliferation are minimized. The IAEA does not have an enforcement or security function but rather it provides independent accounting and auditing functions.

Surveillance by IAEA can serve to heighten awareness and thereby improve security.

- Inclusion of a public information outreach provision in the project plan.

DOE is actively pursuing public outreach. Public confidence in the project can be enhanced by providing information to the local public on nonproliferation objectives, technologies to be used, provisions and regulations to protect the health and safety of workers and the public, experience in handling radioactive materials, advantages of the selected site and disposition option, inspections, etc. Establishment of community working groups should be considered as one means to foster dialog and a flow of information in both directions.

- Education of the general public about radioactivity, atomic energy, and nuclear power and the relative risks associated with the use of these and other modern technologies.

LLNL's letter, "A Perspective on the Dangers of Plutonium," was cited on page 9 and at footnote 12 as an example of reliable information that should be provided to the public, particularly where plutonium is involved. Difficulties are the length of time required to carry-out an educational program that will reach a large portion of the public and establishing the responsibility for public education in the DOE or another federal agency.

- Early Notice to Affected Non-Governmental Entities: Electricity Generation Option.

If the option to use excess plutonium as a reactor fuel is considered, particularly in a new reactor, there are a number of organizations involved in electric power supply planning that should be brought into the planning process early. These include electric utilities on the grid, state public service commissions

20 "Final Generic Environmental Statement on the Use of Recycled Plutonium in Mixed Oxide Fuel in Light Water Cooled Reactors; Health, Safety, and the Environment." Office of Nuclear Materials, Safety, and Safeguards; U.S. Nuclear Regulatory Commssion. NUREG-0002, August 1976. 
for the affected states, the National Electric Reliability Council and the appropriate regional council. ${ }^{21}$

\section{Characteristics of a Project Capable of Avoiding Unnecessary Delay and Achieving Timely Licensing}

As discussed earlier, project design should minimize vulnerability to unnecessary legal and administrative delays and enable the project to survive some level of public and political controversy in order to achieve, in a timely manner, the goals which have been legally established as public policy by Congress or the Administration. The concept of a project with minimum vulnerability responds to the probability that there will, inevitably, be some level of public and political opposition to the excess plutonium disposition program that is potentially capable of delaying the project and preventing it from achieving those goals in a timely manner and at reasonable cost. The importance of timely implementation cannot be overstated. Indeed, the National Academy report, which, as noted earlier, warns against indefinite storage, states:

One of the key criteria by which disposition options should be judged is he speed with which they can be accomplished, and thus the degree to which they curtail the risks of prolonged storage. 22

Some characteristics of a program and projects which may help prevent unnecessary delay are,

21 For elaboration on the last three points, reference is made once again to the Final Report of the Secretary of Energy Advisory Board Task Force on Radioactive Waste Management, "Earning Public Trust and Confidence: Requisites for Managing Radioactive Waste." The following recommendations for "interactions with extemal parties" are taken from the Executive Summary:

o Early and continuous involvement of state and local advisory groups as well as national advisory bodies on which a broad range of stakeholders (including, but not limited to the nuclear industry, electric utilities, public utility commissions, potential host and corridor states, communities, and tribes, environmental and public interest groups) are represented. That involvement would be characterized by frequent contact, complete candor, rapid and full response to questions, use of at least some suggestions, and assistance in increasing the technical and oversight skills of the community;

- Carrying out agreements unless modified through an open process established in advance;

- Consistent and respectful efforts to reach out to state and community leaders and to the general public for the purpose of informing, consulting, and collaborating with them about the technical and operational aspects of Departmental activities;

- Active, periodic presence of very high level agency leaders making themselves visible and accessible to citizens and their representatives;

- Unmistakable agency and program residential presence in the locality that contributes its energies to community affairs and pays through appropriate mechanisms its fair share of the tax burden; and

o Assuring the availability of negotiated benefits for the community along with the resources to affected host and corridor communities that might be needed to detect and respond to unexpected costs.

22 NAS Report, page 237. 
- Strong legislative or administrative mandate.

Serious consideration should be given to seeking a strong, explicit mandate from the Congress for the excess plutonium disposition program. A statutory mandate, apart from, and in addition to, annual budget authorization is preferable. A statutory mandate need not be prescriptive. It can leave to the DOE the authority to define and select an option or options as well as manage the program. A strong statutory framework can reduce the project's vulnerability to legal challenge and will provide guidance to the courts as well as the administrative agencies charged with implementing the law. Authorizing legislation can be used to firmly set regulatory oversight jurisdiction in cases where there might be doubt or overlap. A mandate resulting from the deliberative legislative process can also help secure public acceptance. Current activities to review long-term options for disposition of fissile nuclear materials were initiated by a Presidential Decision Directive issued September 27, 1993 as part of the effort to prevent the proliferation of nuclear weapons. (See page 2.)

- Minimum number of licenses required and levels of government involved.

The less institutionally complicated the project and the fewer the number of licenses required the better. Both disposal and conversion-to-energy options for excess plutonium involve a number of steps, each of which might require a separate facility. Weapon dismantlement, fuel fabrication, waste form preparation and packaging, and finally conversion or disposal are discrete steps which do not necessarily have to be collocated. In theory, each step in the process might require a separate license, even if all from only one or two agencies such as NRC and EPA.

- Project is not "greenfield" but utilizes (an) existing facility(ies) or site(s), preferably on government land or in a government facility.

Where use of existing federal government facilities, or land owned by the federal government, or collocation is possible, licensing may be simplified and the probability of timely completion increased.

\section{Because of Controversy, Project Planning Must Be Carried-Out Under Regulatory and Political Uncertainty}

The overall goals for a disposition policy have been set by the President in his September, 1993 statement, but the issues involved are, and will remain, controversial. DOE planning needs to anticipate that widely differing views exist, and these have already emerged within government and the public input process. Regardless of the openness of the planning process, some elements of opposition will inevitably remain active long after administrative or even legislative and public consensus have been reached. Many of the actions necessary to solidify the disposition plan require major regulatory and institutional steps that are without clear historical precedent.

Planning must be done in the face of uncertainty. It is important to reduce vulnerability to legal, regulatory, and administrative delays by careful planning and legal review, intergovernmental cooperation, peer review, open debate, and strong leadership at the highest levels of government. Enhanced efforts to achieve a high level of public understanding are vital in order to build public and political support for the necessary 
actions and appropriations. The making of decisions and their implementation should be done with the absolute minimum of classification or restriction to information.

During both the planning and decision making process and as implementation proceeds, there will be opposition that will attempt to delay, and may be capable of delaying, the plutonium disposition program and preventing it from reaching its goals in a timely manner and at reasonable cost. Delays and cost overruns can cause erosion of public and political support - leading to further delays.

There is a growing understanding that there needs to be a disposition plan for excess weapons plutonium, and that regardless of what option or options are chosen, interim secure storage is needed in the short term. It will be important to structure the program in such a manner that interim storage can proceed even though complete plans may not have been adopted for the full disposition program.

Once a plan is in place, it will take time to design and build storage facilities, to dismantle warheads, and place materials in storage. Even these steps may run up against unexpected delays in meeting regulatory requirements. The longer a project takes, the greater the risk that unexpected events may occur that could jeopardize the effort.

The importance of timely implementation cannot be overstated. As noted earlier, the National Academy report warns against indefinitely extended storage. Once a consensus has been reached on disposition and decisions have been made and announced, along with their rationale, the need for storage will be clear, and actions needed to prepare for and begin storage will be able to proceed with less risk of unexpected delay. Steady progress toward meeting the important milestones that will be announced will be critical in maintaining public support.

It is only wishful thinking to believe that controversy, opposition, and delays can be avoided solely by selection of the disposal option. Use of excess weapons plutonium as MOX fuel in reactors will face opposition from those who see burning of MOX as legitimizing reprocessing and recycling (even though, in the case of plutonium disposition the reprocessed and separated plutonium already exists). They and other interest groups, and some who are active in arms control and international security, are concerned that there is an increased proliferation potential related to production and use of MOX fuel. Conversely, a decision to declare a significant quantity of excess plutonium to be waste to be committed to permanent disposal would be strongly opposed by those concerned about future energy needs and supplies.

Some groups have successfully delayed or stopped efforts to dispose of high-level waste, spent fuel, and low-level waste by political action and regulatory and legal challenges. Their objectives vary: some are opposed to nuclear energy production in reactors, others are opposed to all uses of radioactive materials in research, industry, and medicine, as well as in energy production.

In choosing among alternative disposition options, decisionmakers should, therefore, anticipate opposition, include time and resources to respond to it, and expect the unexpected.

As indicated in the previous section, factors that could reduce regulatory and political uncertainty include:

- A strong legislative or administrative mandate. 
- Design of the project to minimize the number of licenses required and the levels of government involved.

- Use of government-owned sites, existing facilities, and experienced personnel.

\section{Conclusions: Process and Performance}

The President's policy statement of September 1993 reflects and adds emphasis to the desire of Americans, as well as others around the globe, to bring down the risk of nuclear weapons proliferation. While there are deep differences of opinion with regard to different approaches and their implications, there is consensus on the overall goal.

DOE's commitment to an open process for evaluation of options for disposition of U.S. excess weapons material is welcomed by all parties and will be an important factor in winning public and political support for the disposition plan. It is also clear that a number of the issues are complex. For a substantial fraction of the American people, the entire issue is not one that occupies any active part of their interests.

In the plan development and decision making period, the opportunity for groups, interests, and members of the public to provide input to the governmental decision making process has high priority. This effort has been successfully launched by DOE. As this period concludes with decisions and plans made and finalized, DOE's efforts will necessarily concentrate on implementation of the plans. DOE's need for public support will continue and must be earned through performance and accountability.

The public expects results for the expenditure of its funds and resources and because of the importance of the undertaking to national security; the public has a right to be informed. (If the program proceeds well, public interest may be low, and this may make the public information task seem harder. But it remains necessary.) DOE will have to provide Congress and the American people the facts about what it is doing and why, the progress that is being made in the overall program and specific projects toward their goals, and about the problems that are being encountered.

Anticipation of institutional issues and effective response to them, openness, and accountability to the public must be integral parts of the government's program for disposition of excess weapons material.

Following the lead of the Final Report of the Secretary of Energy Advisory Board Task Force on Radioactive Waste Management, "Earning Public Trust and Confidence: Requisites for Managing Radioactive Wastes," this paper has placed great emphasis on process in securing public and political acceptance, i.e., public trust and confidence. However, it must be kept in mind that in the long run, and for the majority of the public, performance counts most of all. This point has been well-stated by Justice Steven Breyer in his book, "Breaking the Vicious Circle, Toward Effective Risk Regulation"23:

"Remember the sharp decline in confidence in public institutions over the past 25 years. Recall, however, that rebuilt trust in institutions is based not simply on the public's perception of openness, but also on the ability of an institution

23 "Breaking the Vicious Circle, Toward Effective Risk Regulation" by Steven Breyer. Harvard University Press, 1993. At the time the book was published, Justice Breyer was Chief Judge, United States Court of Appeals for the First Circuit. 
to accomplish its mission successfully, particularly where that mission itself helps to achieve an important public purpose."

[Page 78.]

and

"...trust in institutions arises not simply as a result of openness in government, responses to local interest groups, or priorities emphasized in the press

though these attitudes and actions play an important role - but also from those institutions' doing a difficult job well."

[Page 81.] 